\section{p-ISSN 2476-9886 \\ e-ISSN 2477-0302 \\ J.Edu}

Volume 3 Nomor 2, 2017, HIm 44-51
Jurnal EDUCATIO

Jurnal Pendidikan Indonesia

Akses Online :

http://jurnal.iicet.org

Dipublikasikan oleh :

Indonesian Institute for Counseling, Education and Therapy (IICET)

Info Artikel:

\title{
MENINGKATKAN HASIL BELAJAR IPS SISWA MELALUI PENGGUNAAN MEDIA GAMBAR
}

\author{
Yenimar
}

SDN 26 Sungai Limau Kabupaten Padang Pariaman

\begin{abstract}
In fact, learning process in some schools still run with teacher centered condition. It caused students feeling bored and not participate actively. To create the active and enjoy learning process, one of solutions is by using media of picture. This study was conducted at 4th grade of SDN 26 Sungai Limau Kabupaten Padang Pariaman.This study is a classroom action research with two cycles. Each of cycle consists of two meetings. Procedure of this research includes four steps, i.e. planning, implementation, observation, and reflection. This study aimed to improve students' learning achievement in social subject by implementing media of picture.Percentage of students' learning achievement in cycle I is $67 \%$ and $81 \%$ for cycle II. Findings and analysis of data show that media of picture can improve students' learning achievement in social subject.
\end{abstract}

Keyword: learning achievement, media of picture, social subject

(c) (f) This is an open access article distributed under the Creative Commons Attribution License, which permits unrestricted use, distribution, and reproduction in any medium, provided the original work is properly cited. (C2017 by author and IICET.

\section{PENDAHULUAN}

Pendidikan merupakan suatu kegiatan yang universal dalam kehidupan manusia, bertujuan untuk membentuk peserta didik yang memiliki wawasan luas serta berdaya guna bagi masyarakat. Hal ini sejalan dengan yang tercantum dalam UUNo.20 Tahun 2003 bahwa "sistem pendidikan nasional bertujuan untuk mengembangkan potensi peserta didik agar menjadi manusia yang beriman, bertaqwa pada Tuhan Yang Maha Esa, berakhlak mulia, berilmu, mandiri dan bertanggung jawab terhadap keluarga, masyarakat, bangsa dan negara".Pendidikan dapat berlangsung di lingkungan keluarga, sekolah, dan masyarakat. Pendidikan yang dilaksanakan di lingkungan sekolah bertujuan untuk mengantarkan peserta didik menuju perubahan tingkah laku baik secara intelektual, moral maupun sosial agar peserta didik dapat hidup mandiri sebagai individu dan makhluk sosial. Proses pembelajaran di sekolah merupakan proses komunikasi yaitu proses penyampaian pesan dan informasi dari guru kepada peserta didik.

Guru sebagai pemberi pesan dalam proses komunikasi harus mampu mengajar, memotivasi, dan merangsang peserta didik untuk dapat menerima informasi berupa materi pembelajaran dengan baik, agar tujuan pembelajaran 
dapat tercapai. Pembelajaran akan berhasil dengan baik apabila guru sebagai fasilitator dan motivator bagi peserta didik tidak hanya mengajar dengan monoton, tetapi bervariasi dalam metode, strategi, pendekatan maupun media pembelajaran. Salah satu hal yang harus dikuasai guru dalam pembelajaran adalah penggunaan media, karena dengan adanya media suasana pembelajaran akan lebih menarik dan peserta didik termotivasi dalam belajar. Hamalik (dalam Azhar, 2006) menegaskan bahwa "penggunaan media dalam pembelajaran dapat membangkitkan keinginan dan minat, membangkitkan motivasi dan rangsangan dalam pembelajaran, serta dapat mempertinggi hasil belajar peserta didik".

Media bagian yang tidak terpisahkan dari pembelajaran, media perantara antara guru dengan peserta didik dalam menyampaikan dan menerima materi pelajaran. Arief (2008) menyatakan bahwa "media adalah segala sesuatu yang dapat digunakan untuk menyalurkan pesan dari pengirim ke penerima sehingga dapat merangsang pikiran, perasaan, perhatian dan minat peserta didik".Media dalam pembelajaran IPS sangat beraneka ragam, semua jenis media memiliki keunggulan dalam pembelajaran, keanekaragaman media pembelajaran dapat diklasifikasikan berdasarkan ciri-cirinya.Media visual mempunyai peran yang sangat penting dalam pembelajaran, media visual dapat memperlancar pemahaman dan memperkuat ingatan peserta didik terhadap suatu materi pelajaran yang dapat menumbuhkan minat dan motivasi yang dapat memberikan hubungan antara isi materi pelajaran dengan dunia nyata. Menurut Azhar (2006) mengatakan bahwa "media visual berupa diagram, peta, grafik dan gambar". Salah satu media yang cocok dalam pembelajaran IPS yaitu media gambar, yang bisa menggambarkan suatu objek sesuai dengan bentuk aslinya.

Dalam menggunakan media gambar, yang harus diperhatikan guru yaitu kriteria pemilihan media gambar. Adapun kriteria pemilihan media gambar yaitu warna gambar menarik bagi peserta didik dan kesesuaian antara isi yang disampaikan gambar dengan materi yang akan diajarkan. Sejalan dengan ini Azhar (2006) mengemukakan bahwa "kriteria pemilihan media gambar yaitu gambar harus sesuai dengan tujuan pembelajaran yang ingin dicapai, gambar harus tepat untuk mendukung isi pelajaran, praktis, dan gambar harus bisa menyampaikan informasi dengan jelas". Melihat begitu banyaknya mamfaat media gambar dalam pembelajaran sudah sepantasnya guru menggunakan media gambar. Kenyataan yang terjadi dilapangan ketika penulis mengadakan observasi, guru jarang menggunakan media gambar dalam pembelajaran, sehingga peserta didik kurang termotivasi dalam belajar akibatnya hasil belajar peserta didik tidak sesuai dengan yang diharapkan. Sedangkan tuntutan dalam KTSP guru hanyalah berfungsi sebagai fasilitator, pusat belajar berada pada peserta didik. Guru hendaknya mampu menggali segala potensi yang ada pada diri peserta didik, semakin berpotensi peserta didik semakin meningkat hasil pembelajaran. Oleh sebab itu penggunaan media gambar dalam pembelajaran IPS merupakan hal yang penting untuk menciptakan pembelajaran yang efektif dan efisien.

Media gambar dalam pembelajaran IPS di sekolah dasar, dapat memvisualkan konsep yang ingin disampaikan kepada peserta didik. Menurut Ahmad (1997) mengemukakan bahwa "gambar dapat membantu guru dalam mencapai tujuan pembelajaran, karena gambar termasuk media yang mudah dan murah serta besar artinya bagi peserta didik untuk mempertinggi nilai pembelajaran. Media gambar menarik perhatian dan minat peserta didik". Sejalan dengan ini Sudjana (2005) juga mengatakan bahwa "media gambar akan lebih menarik bagi peserta didik dibandingkan dengan cerita guru tentang suatu materi pembelajaran". Pada umumnya peserta didik usia sekolah dasar senang dengan gambar apalagi adanya perpaduan warna yang menarik, sehingga peserta didik akan termotivasi dalam belajar dan hasil belajar yang diinginkan akan meningkat.

Sewaktu penulis melakukan wawancara dengan guru kelas IV SD Negeri 26 Sungai Limau Kecamatan Sungai Limau Kabupaten Padang Pariaman, Penulis meminta rekapitulasi nilai hasil belajar peserta didik pada suatu materi IPS untuk melihat sejauh mana pemahaman peserta didik dalam pembelajaran. Peserta didik yang mendapatkan nilai 2 satu orang, nilai 3 satu orang, nilai 4 empat orang, nilai 5 empat orang, nilai 6 tiga orang, nilai 7 empat orang, nilai 8 dua orang, nilai 9 dua orang, dan nilai 10 satu orang, dengan rata-rata kelas 5,9. Jelaslah penggunaan media gambar sangat penting untuk meningkatkan hasil belajar peserta didik.

\section{METODE}

Jenis penelitian ini adalah Penelitian Tindakan Kelas (PTK), yaitu proses yang dilakukan perorangan atau kelompok yang menghendaki perubahan dalam situasi tertentu. PTK sebagai suatu bentuk investigasi yang bersifat reflektif hasil belajar, kolaboratif dan spiral, yang memiliki tujuan untuk melakukan perbaikan sistem, 
metode kerja, proses, isi, kompetensi dan situasi.Penelitian dilakukan dalam dua siklus dimana setiap siklus terdiri dari dua kali pertemuan. Setiap siklus terdiri atas tahap perencanaan, pelaksanaan, pengamatan, dan refleksi. Penelitian ini dilaksanakan di SD Negeri 26 Sungai Limau Kecamatan Sungai Limau. Lokasi ini dipilih sebagai tempat penelitian karena di sekolah ini belum menggunakan media dalam mengajar IPS.

Penelitian tindakan kelas ini dilakukan pada peserta didik kelas IV SD Negeri 26 Sungai LimauKabupaten Padang Pariaman, dengan jumlah peserta didik 22 orang yang terdiri dari 10 orang laki-laki dan 12 orang perempuan.Data penelitian ini dikumpulkan dengan menggunakan pencatatan lapangan, observasi, wawancara dan hasil tes. Adapun kriteria keberhasilan setiap tindakan adalah sebagai berikut (1) hasil observasi guru dan siswa telah menunjukkan bahwa dalam pelaksanaan pembelajaran sesuai dengan rencana yang ditetapkan; (2) hasil LKS telah menunjukkan bahwa dua pertiga dari kelompok yang ada telah meneyelesaikan dengan baik; (3) hasil tes akhir dari semua subjek telah memperoleh skor lebih dari atau sama dengan 80\%; dan (4) hasil wawancara telah memberikan informasi bahwa siswa senang mengikuti pelajaran.

\section{HASIL DAN PEMBAHASAN}

Hasil

\section{Deskripsi Siklus 1}

\section{Perencanaan}

Berdasarkan studi awal, disusun perencanaan tindakan siklus I yang dilaksanakan dalam dua kali pertemuan dengan alokasi waktu 4 x 35 menit. Terlebih dahulu disusun Rencana Pelaksanaan Pembelajaran (RPP) dan soalsoal latihan peserta didik sebagai instrumen penunjang dalam penelitian.

\section{Pelaksanaan}

Pelaksanaan pembelajaran dibagi ke dalam tiga kegiatan pembelajaran, yaitu kegiatan awal, inti, dan kegiatan akhir, semua kegiatan pembelajaran ini sesuai dengan langkah-langkah penggunaan media gambar. Materi pelajaran yang dipilih pada siklus I adalah perkembangan teknologi komunikasi dengan menggunakan media gambar. Pelaksanaan dilakukan dalam dua kali pertemuan.Pada akhir kegiatan, peserta didik melalui bimbingan guru menyimpulkan materi pelajaran tentang perkembangan teknologi komunikasi dilanjutkan dengan pemberian evaluasi.

\section{Pengamatan}

Dari pengamatan yang diamati observer pada siklus I sewaktu guru menyampaikan tujuan pembelajarankurang jelas sehingga peserta didik kurang serius mendengarkan penjelasan guru dan peserta didik tidak mengerti tujuan pembelajaran yang disampaikan guru, dimana ada peserta didik yang masih berbicara dengan temannya. Pada kegiatan inti pada waktu guru menjelaskan materi terlihat sebagian dari peserta didik masih ada yang berbicara dengan temannya, sehingga masih ada di antara peserta didik yang tidak mengerti materi yang dijelaskan oleh guru. Sewaktu peserta didik diberi kesempatan untuk mengajukan pertanyaan, masih ada peserta didik yang kurang bisa untuk berbicara dan sewaktu guru mengajukan beberapa pertanyaan kepada peserta didik, beberapa orang dari peserta didik terlihat malu-malu untuk berbicara walaupun mereka tahu tapi masih malu untuk mengungkapkan karena takut salah.

Tabel 1. Hasil Belajar Siswa Pada Siklus I

\begin{tabular}{ccccc}
\hline Responden & \multicolumn{3}{c}{ Hasil Belajar Siklus I } & \multirow{2}{*}{ Rata-Rata Siklus I } \\
\cline { 2 - 4 } $\mathbf{1}$ & Kognitif & Afektif & Psikomotor & \\
$\mathbf{2}$ & 5 & 5 & 6 & $\mathbf{5 , 3}$ \\
$\mathbf{3}$ & 6 & 7 & 6 & $\mathbf{6 , 3}$ \\
$\mathbf{4}$ & 5 & 5 & 4 & $\mathbf{4 , 7}$ \\
& 10 & 9 & 8 & $\mathbf{9 , 0}$ \\
\hline
\end{tabular}




\begin{tabular}{ccccc}
\hline $\mathbf{5}$ & & & & \\
$\mathbf{6}$ & 4 & 3 & 4 & $\mathbf{3 , 7}$ \\
$\mathbf{7}$ & 6 & 7 & 6 & $\mathbf{6 , 3}$ \\
$\mathbf{8}$ & 9 & 8 & 8 & $\mathbf{8 , 3}$ \\
$\mathbf{9}$ & 5 & 5 & 6 & $\mathbf{5 , 3}$ \\
$\mathbf{1 0}$ & 6 & 5 & 6 & $\mathbf{5 , 7}$ \\
$\mathbf{1 1}$ & 6 & 7 & 6 & $\mathbf{6 , 3}$ \\
$\mathbf{1 2}$ & 8 & 7 & 8 & $\mathbf{7 , 7}$ \\
$\mathbf{1 3}$ & 9 & 8 & 8 & $\mathbf{8 , 3}$ \\
$\mathbf{1 4}$ & 6 & 6 & 6 & $\mathbf{6 , 0}$ \\
$\mathbf{1 5}$ & 5 & 5 & 6 & $\mathbf{5 , 3}$ \\
$\mathbf{1 6}$ & 9 & 8 & 8 & $\mathbf{8 , 3}$ \\
$\mathbf{1 7}$ & 7 & 7 & 8 & $\mathbf{7 , 3}$ \\
$\mathbf{1 8}$ & 7 & 7 & 8 & $\mathbf{7 , 3}$ \\
$\mathbf{1 9}$ & 8 & 8 & 6 & $\mathbf{7 , 3}$ \\
$\mathbf{2 0}$ & 7 & 7 & 6 & $\mathbf{6 , 7}$ \\
$\mathbf{2 1}$ & 7 & 7 & 6 & $\mathbf{6 , 7}$ \\
$\mathbf{2 2}$ & 7 & 8 & 8 & $\mathbf{7 , 7}$ \\
Rata-rata & 8 & 7 & 8 & $\mathbf{7 , 7}$ \\
\hline Persentase & 6,8 & 6,6 & 6,6 & $\mathbf{6 , 7}$ \\
\hline
\end{tabular}

\section{Refleksi}

Hasil pengamatan dan tes selama pelaksanaan tindakan dianalisis dan didiskusikan dengan pengamat sehingga diperoleh hal-hal sebagai berikut: guru membangkitkan skemata peserta didik dimana peserta didik kurang aktif dan kurang semangat dalam menjawab pertanyaan yang dilontarkan oleh guru; dalam menyampaikan tujuan pembelajaran guru kurang jelas sehingga peserta didik kurang serius mendengarkan penjelasan dari guru; guru kurang memberikan pujian kepada peserta didik yang aktif dalam menjawab pertanyaan guru; pada saat peserta didik diminta untuk menceritakan pengalaman menggunakan alat komunikasi kedepan kelas, peserta didik pertama agak mengalami kesulitan karena mereka masih malu-malu untuk mengungkapkan ide-ide yang ada karena ini baru pertama kali dilakukan. Setelah peserta didik diberi bimbingan oleh peneliti sebagian peserta didik dapat memahaminya, sedangkan sebagian lagi masih diberi semangat untuk berani berbicara dan mengungkapkan ide-idenya; suasana kelas untuk belajar mulai hidup; kegairahan peserta didik untuk mengikuti pelajaran mulai tumbuh; cara bicara guru agak cepat dan bahasa yang digunakan kurang dipahami peserta didik; peserta didik sudah mulai berani untuk menanggapi, walaupun masih sedikit; pujian dari guru masih kurang sehingga peserta didik kurang termotivasi selama pembelajaran.

Berdasarkan pengamatan dan penilaian maka tujuan pembelajaran yang diharapkan pada siklus I belum tercapai. Dengan demikian upaya untuk mencapai tujuan pembelajaran dengan menggunakan media gambar akan ditargetkan pada siklus II dengan menggunakan langkah-langkah yang sama pada siklus I.

\section{Deskripsi Siklus 1}

\section{Perencanaan}

Untuk memperbaiki kelemahan dan mempertahankan keberhasilan yang telah dicapai pada siklus I maka pada pelaksanaan siklus II dapat di buat perencanaan sebagai berikut: menyampaikan tujuan pembelajaran dengan jelas sehingga peserta didik dapat serius dalam belajar dan memahami apa yang disampaikan guru; memberikan motifasi pada peserta didik sehingga menimbulkan minat peserta didik dalam belajar; menggali jawaban dari peserta didik sehingga peserta didik dapat memberikan jawaban terhadap pertanyaan-pertanyaan yang di lontarkan guru; membimbing peserta didik agar mampu mengeluarkan ide-ide dan pendapat; memberikan penjelasan kepada 
peserta didik cara menceritakan pengalamannya masing-masing menggunakan alat komunikasi di buku tulisnya masing-masing; guru lebih memotivasi peserta didik dengan memberikan pujian dan penghargaan kepada peserta didik yang aktif dalam pembelajaran.Materi pelajaran yang telah dilaksanakan pada siklus II adalah perkembangan teknologi transportasi dengan menggunakan media gambar.

\section{Pelaksanaan}

Pelaksanaan pembelajaran dibagi dalam tiga kegiatan pembelajaran yaitu kegiatan awal, inti, dan kegiatan akhir, semua kegiatan pembelajaran ini sesuai dengan langkah-langkah penggunaan media gambar, yang langkah pembelajarannya sama dengan langkah pembelajaran pada sikus I. Materi yang disajikan adalah perkembangan teknologi transportasi dengan menggunakan media gambar.

\section{Pengamatan}

Pada pembelajaran siklus ke II memperlihatkan hasil yang memuaskan, guru dengan sangat baik membangkitkan skemata peserta didik, yaitu dengan menanyakan pelajaran yang telah dipelajari dengan tujuan menguji sampai dimana kemampuan peserta didik mengingat pelajaran yang telah dipelajarinya. Dalam menyampaikan tujuan pembelajaran peneliti terlihat sangat baik dan jelas sehingga peserta didik serius dalam mendengarkan penjelasan guru dan memahami apa yang disampaikan oleh guru.Dalam kegiatan inti menurut guru kelas sebagai pengamat, peneliti sebagai guru dalam menyampaikan materi pembelajaran terlihat sudah baik, dimana peneliti dalam menjelaskan pembelajaran dengan menggunakan media gambar.

Tabel 2. Hasil Belajar Siswa Pada Siklus II

\begin{tabular}{|c|c|c|c|c|}
\hline \multirow[t]{2}{*}{ Responden } & \multicolumn{3}{|c|}{ Hasil Belajar Siklus II } & \multirow[t]{2}{*}{ Rata-Rata Siklus II } \\
\hline & Kognitif & Afektif & Psikomotor & \\
\hline 1 & 8 & 7 & 6 & 7,0 \\
\hline 2 & 7 & 7 & 8 & 7,3 \\
\hline 3 & 6 & 6 & 6 & 6,0 \\
\hline 4 & 10 & 10 & 10 & 10 \\
\hline 5 & 6 & 6 & 6 & 6,0 \\
\hline 6 & 7 & 7 & 8 & 7,3 \\
\hline 7 & 10 & 8 & 10 & 9,3 \\
\hline 8 & 9 & 9 & 10 & 9,3 \\
\hline 9 & 9 & 8 & 8 & 8,3 \\
\hline 10 & 7 & 8 & 6 & 7,0 \\
\hline 11 & 9 & 9 & 10 & 9,3 \\
\hline 12 & 10 & 9 & 10 & $\mathbf{9 , 7}$ \\
\hline 13 & 8 & 7 & 8 & 7,7 \\
\hline 14 & 7 & 7 & 8 & 7,3 \\
\hline 15 & 10 & 9 & 10 & $\mathbf{9 , 7}$ \\
\hline 16 & 8 & 8 & 8 & 8,0 \\
\hline 17 & 8 & 9 & 8 & 8,3 \\
\hline 18 & 9 & 8 & 8 & 8,3 \\
\hline 19 & 8 & 7 & 8 & 7,7 \\
\hline 20 & 8 & 7 & 6 & 7,0 \\
\hline 21 & 8 & 9 & 8 & 8,3 \\
\hline 22 & 9 & 8 & 8 & 8,3 \\
\hline Rata-rata & 8,2 & 7,9 & 8,1 & 8,1 \\
\hline Persentase & $82 \%$ & $79 \%$ & $81 \%$ & $81 \%$ \\
\hline
\end{tabular}


Rata-rata hasil belajar siklus II yang diperoleh peserta didik ranah kognitif 8,2 atau persentase ketuntasan klasikal $82 \%$, ranah afektif 7,9 atau persentase ketuntasan klasikal 79\%, dan ranah psikomotor 8,1 atau persentase ketuntasan klasikal $81 \%$. Dengan demikian dapat dikatakan hasil belajar peserta didik pada siklus II ranah kognitif, afektif, dan psikomotor 8,1 atau persentase ketuntasan klasikal peserta didik 81\%.Begitu juga dengan persentase ketuntasan belajar klasikal peserta didik ranah kognitif, afektif dan psikomotor dari siklus I ke siklus II mengalami peningkatan. Persentase ketuntasan belajar klasikal peserta didik ranah kognitif pada siklus I adalah 68\% meningkat menjadi $81 \%$ pada siklus II. Persentase ketuntasan belajar klasikal peserta didik ranah afektif pada siklus I yaitu $66 \%$ meningkat menjadi $79 \%$ pada siklus II. Begitu pula dengan persentase ketuntasan belajar klasikal peserta didik untuk ranah psikomotor pada siklus I yaitu $66 \%$ meningkat pada siklus II menjadi $81 \%$. Berpatokan kepada standar ideal ketuntasan belajar sekolah (70\%) dan data penelitian siklus II, maka dapat dinyatakan bahwa penelitian pada siklus II ini telah memenuhi kriteria ketuntasan belajar.

\section{Refleksi}

Berdasarkan hasil kolaborasi peneliti dengan guru kelas yang bertindak sebagai pengamat, maka disimpulkan bahwa dalam pelaksanaan pembelajaran pada siklus II adalah lebih baik, bila dibandingkan dengan pembelajaran pada siklus I. Hal ini dapat kita lihat bahwa berdasarkan hasil refleksi yang ada pada siklus I, maka pada siklus II ini pelaksanaan pembelajaran sudah berjalan dengan baik. Berdasarkan hasil kolaborasi dikatahui bahwa penggunaan media gambar pada pembelajaran IPS dapat membantu dan mempermudah peserta didik untuk menguasai materi, jika dengan hapalan tidak dapat dikuasai peserta didik dengan sempurna. Pada saat peserta didik ditugaskan oleh guru untuk menjelaskan jawaban pertanyaan yang diberikan guru semua peserta didik aktif untuk menjelaskan, peserta didik lain mengangkat tangan ingin menanggapi atau menambah penjelasan yang telah diuraikan dari temannya dengan suara yang keras dan bahasa yang jelas, terlihat tidak ada lagi siswa yang diam atau malu berbicara mereka dengan serius mendengarkan apa yang dibuat dan dijelaskan temannya. Pelaksanaan pembelajaran dengan menggunakan media gambar mengenai perkembangan teknologi transportasi telah berhasil dilaksanakan yang dapat terlihat dari nilai rata-rata yang diperoleh sudah mencapai 8,1. Kemudian dapat disimpulkan bahwa hasil belajar peserta didik pada pembelajaran IPS dapat meningkat dengan menggunakan media gambar.

\section{Pembahasan}

\section{Siklus I}

Pada siklus I, materi disampaikan dengan menggunakan media gambar dan pelaksanaan pembelajarannya disesuaikan dengan langkah-langkah penggunaan media gambar. Hasil belajar siswa belum sesuai dengan yang diinginkan. Padahal, hasil belajar merupakan tolak ukur untuk menentukan keberhasilan peserta didik dalam memahami pembelajaran. Sebagaimana yang dikemukakan oleh Oemar (2008) bahwa "hasil belajar adalah perubahan tingkah laku yang timbul, misalnya dari yang tidak tahu menjadi tahu, timbulnya pertanyaan baru, perubahan dalam tahap kebiasaan, perkembangan sikap sosial dan emosional peserta didik".Berdasarkan catatan hasil di lapangan dan diskusi peneliti dengan guru kelas IV, penyebab belum berhasilnya pembelajaran pada siklus I dengan menggunakan media gambar disebabkan guru kurang efektif dalam menyampaikan materi sehingga langkah-langkah pembelajaran masih ada yang belum terlaksana dengan sempurna sesuai dengan yang direncanakan. Disini peneliti juga kurang teliti dalam langkah-langkah pembelajaran.Dari siklus I ini dapat dilihat bahwa hasil belajar peserta didik masih rendah sehingga siklus I dinyatakan belum berhasil sehingga dilanjutkan ke siklus II.

\section{Siklus II}

Pembelajaran alat transportasi dengan menggunakan media gambar pada siklus II dapat dilaksanakan dengan baik karena pelaksanaan pembelajaran telah sesuai dengan rencana pelaksanaan pembelajaran. Berdasarkan catatan hasil di lapangan dan diskusi peneliti dengan guru kelas IV, penyajian materi berhasil dilaksanakan dengan langkah-langkah pembelajaran sesuai dengan langkah-langkah penggunaan media gambar.Pada siklus II 
materi yang disampaikan perkembangan teknologi transportasi dengan menggunakan media gambar dan pelaksanaan pembelajarannya disesuaikan dengan langkah-langkah penggunaan media gambar.Hasil belajar peserta didik pada siklus II sesuai dengan yang diinginkan.Berdasarkan hasil pengamatan siklus II yang diperoleh maka pelaksanaan siklus II sudah baik dan guru sudah berhasil dalam usaha peningkatan hasil belajar peserta didik dalam pembelajaran perkembangan teknologi transportasi dengan menggunakan media gambar bagi peserta didik kelas IV SDN 26 Sungai Limau Kabupaten Padang Pariaman.

Keberhasilan ini dianggap sebagai efek dari penggunaan media gambar dalam pembelajaran. Sesuai dengan apa yang telah disampaikan oleh para ahli. Media gambar memiliki multi fungsi dalam pembelajaran, media gambar paling sering digunakan dalam menyampaikan materi pelajaran karena dalam pembelajaran tidak mungkin menghadirkan benda nyata atau benda yang sebenarnya kedalam kelas. Menurut Wibawa (1991) media gambar berfungsi sebagai berikut: 1) Mengembangkan imajinasi peserta didik, 2) Membantu meningkatkan penguasaan peserta didik terhadap hal-hal yang abstrak atau peristiwa yang tidak mungkin dihadirkan kedalam kelas, 3) Mengembangkan kreativitas peserta didik. Media gambar bisa menyampaikan pesan dalam pembelajaran, memberikan kesan yang menarik perhatian bagi orang yang melihatnya, mudah dimengerti,mempunyai daya guna serta daya tarik karena adanya perpaduan warna yang menarik. Senada dengan Mujadi (1995) yang mengatakan bahwa media gambar merupakan alat peraga yang penting dalam pembelajaran karena gambar dapat memberikan informasi yang diperlukan tentang benda atau masalah yang di gambarkan. Seperti halnya model, gambar berfungsi sebagai pengganti benda aslinya jika benda yang sebenarnya tidak mungkin didatangkan diruang belajar, maka biasanya digunakan gambar sebagai penggantinya karena gambar mudah didapat dan mudah membuatnya.

\section{SIMPULAN DAN SARAN}

Dari uraian yang telah disampaikan di atas, maka dapat disimpulkan sebagai berikut. Pertama, sebelum melakukan pembelajaran guru terlebih dahulu perlu membuat rancangan pelaksanaan pembelajaran sesuai dengan langkah-langkah pembelajaran. Rancangan Pelaksaan Pembelajaran (RPP) dengan menggunakan media gambar berisi standar kompetensi, kompetensi dasar, indikator, tujuan pembelajaran, materi pokok, kegiatan pembelajaran, metode/sumber/media, serta evaluasi. Kedua, pelaksanaan pembelajaran IPS dengan menggunakan media gambar sesuai dengan langkah-langkah penggunaan media gambar yang terdiri dari 9 langkah diawali dengan menyiapkan alat-alat dan bahan yang akan digunakan selama pembelajaran, menyampaikan tujuan pembelajaran, memberikan pengantar untuk menimbulkan minat peserta didik, memperagakan gambar, meminta pendapat peserta didik, menjelaskan materi melalui media gambar, mengajukan pertanyaan, menyimpulkan materi pelajaran, dan memberikan evaluasi. Ketiga, pelaksanaan pembelajaran IPS dengan menggunakan media gambar dilaksanakan dua siklus, masing-masing siklus terdiri dua kali pertemuan dengan 4 tahap yaitu perencanaan, pelaksanaan, pengamatan, dan refleksi. Keempat, pembelajaran dengan menggunakan media gambar dapat meningkatkan hasil belajar peserta didik yang terlihat pada rata-rata hasil belajar siklus II lebih meningkat dari siklus I, dimana pada siklus I rata-rata yang didapat 6,8. Sedangkan siklus II rata-rata yang didapat adalah 8,1.

Berdasarkan hasil pembelajaran dengan penggunaan media gambar pada kelas IV SD Negeri 26 Sungai Limau Kabupaten Padang Pariaman maka dikemukakan saran sebagai berikut. Pertama, diharapkan guru hendaknya dapat membuat rancangan pembelajaran dengan menggunakan media gambar dalam pembelajaran IPS, agar pembelajaran berlangsung efektif dan efisien. Kedua, diharapkan guru dapat melaksanakan pembelajaran IPS dengan menggunakan media gambar yang mana pelaksanaan pembelajarannya sesuai dengan langkah-langkah pembelajaran dengan menggunakan media gambar. Ketiga, diharapkan kepada guru agar dapat meningkatkan hasil belajar yang diperoleh peserta didik dengan menggunakan media gambar dalam mata pelajaran IPS.

\section{DAFTAR RUJUKAN}

Azhar,Arsyad. (2006). Media Pembelajaran. Jakarta: Raja Grafindo Persada.

Ahmad, Rohani. (1997). Media Intruksional Edukatif. Jakarta: Rineka Cipta. 
Arief,Sadiman S.dkk. (2008). Media Pendidikan. Jakarta: Raja Grafindo Persada.

Sudjana, Nana. (2005). Media Pengajaran. Bandung: Sinar Baru Algensindo.

Oemar, Hamalik. (2008). Proses Belajar Mengajar. Jakarta: Bumi Aksara.

Wibawa,Basuki. (1991). Media Pengajaran. Jakarta: Depdikbud.

Mujadi. (1995). Materi Pokok Desain dan Alat Peraga. Jakarta: Dirjen Pendidikan Dasar dan Menengah. 